\title{
SURFING THE WAVES OF SELF-REGULATED LEARNING TO EVALUATE FLIPPED CLASSROOMS (FC)
}

\author{
Jorge Reyna \\ Faculty of Science, University of Technology Sydney (AUSTRALIA) \\ jorge.reyna@uts.edu.au
}

\begin{abstract}
Flipped classrooms (FC) are becoming a standard instructional strategy in higher education in the last five years. Although the research in the field is increasing, it is still considered in its infancy and with the lack of pedagogical integrity. Most of the studies up to date do not count on solid theoretical foundations and assumed students would buy-in this way of instruction. There are limited frameworks available to guide FC implementations, and most of them consider three stages: before, during and after the classroom. A research gap has been identified; there is not any model available to evaluate learning in FC. This paper offers an evidence-based framework to measure self-regulation learning during FC. The model links goal setting, environmental structuring and time management before the classroom. During the classroom, task strategies and help-seeking and self-evaluation and self-consequences after the classroom. The aim is to gain an in-depth understanding on how students self-regulate their learning in FC interventions. Implications for the implementation of FC are considered.
\end{abstract}

Keywords: Flipped learning, flipped classrooms, flip learning, flipped classrooms, evaluation, selfregulated learning

\section{INTRODUCTION}

Flipped classroom (FC) is becoming a dominant pedagogical and instructional strategy in higher education. In FC interventions, the student works with the preparation material online before the classroom, active participation during the classroom and reflection after the classroom (Reyna, 2015). This mode of instruction redefines face-to-face transmissive lectures, and it is improved using technology (Abeysekera \& Dawson, 2015). The FC does not constitute a new approach, in fact, the Thayer method can be considered a precursor of FC. Designed by Sylvanus Thayer from the United States Military Academy almost 200 years ago, engaged cadets in their learning preparing before the classroom. During the classroom, they reinforced their learning through a combination of group collaboration and active learning using blackboards (Shell, 2002). The FC was popularised in 2007 in high school chemistry classes. Using a simple approach (PowerPoint with audio uploaded onto the web) and students need to engage with the content before the classroom. During classroom time, students will be asked to participate in learning activities (Bergmann \& Sams, 2012). The main ingredient of the FC approach is called 'active learning', where students engage in learning by doing rather than being passive. Research in FC is under-evaluated, under-theorised and under-researched (Abeysekera \& Dawson, 2015; Chen et al., 2014). Universal features of FC include content delivered before the classroom, teachers testing students on the material during the classroom, and promotion of higher-order thinking via group collaboration and participation (O'Flaherty \& Phillips, 2015).

In traditional lecture settings, students do not have the time to understand, critically analyse, apply and reflect on the knowledge being presented (Du et al., 2014). During lectures, due to cognitive overload, students may get distracted and disengaged (Clark et al., 2011). In contrast, FC allows flexibility and additional time to consolidate ideas and reflection. But the principal advantage is that can provide students with the opportunity to practice, apply knowledge and gain new skills. During the class time, students can act as teachers, explaining concepts to their peers causing the classroom to be a collaborative learning environment (Lane, 2015). This peer teaching foster a higher level of critical thinking and reasoning skills (Moraros et al., 2015), cognitive development and it will encourage innovation through 
collaborative processes (McLaughlin et al., 2013). Active learning during the class can foster several skills such as individual inquiry and collaborative effort, social aspects and cultural awareness, and further develop independent lifelong learning skills (Bergmann \& Sams, 2012; Du et al., 2014). When the rationale behind FC is communicated to students, could help them to master knowledge and skills, stimulate enthusiasm and initiative, and improve the ability to solve problems and innovate (Huan, 2016). If the FC uses pre-recorded material, this could help English as an Additional Language (EAL) students (Du et al., 2014) and can be expected to result in a better management of working memory (Clark et al., 2005). Research pointed that FC improves students' self-direction and invites them to be responsible for their learning (Bergmann \& Sams, 2012). From the self-regulation and motivational factors perspective, this claim has not been explored further.

The literature reports hurdles to implementing the FC from the student's opinion. One of the major drawbacks has been identified to be student's capacity to engage in preparation before the classroom, and the readiness of transformation from passive to active learners (Straw, 2015). There is a concern that the FC will not support active learning if students fail to engage in pre-work activities (Kachka, 2012). Most of the research done in FC effectiveness are based on student perceptions rather than an accurate assessment of students' performance (Bishop \& Verleger, 2013). A combination of evaluative strategies such as (1) educator reflection; (2) student perceptions; (3) student assessment achievement; and, (4) student actions (Phillips et al., 2012) will be an ideal way to gain an in-depth understanding of FC interventions. Such a strategy will gather information to decide on how to improve the FC experience for the students.

The aim of this paper is to propose a theoretical framework based on self-regulation and motivational theory (Zimmerman \& Schunk, 2011) to evaluate how students are learning when FC is used as an instructional strategy. This model will meet the needs for an evidence-based instrument to measure self-regulation during FC.

\section{SELF-REGULATION THEORY AND MOTIVATIONAL FACTORS}

One of the primary goals of higher education is to promote lifelong learning skills. Graduates should develop self-directed learning skills and ability to acquire and master the latest knowledge effectively. The ability to keep pace with the explosive nature of the information that characterises the $21^{\text {st }}$ century is highly regarded by employers.

\subsection{Self-Regulation}

Self-regulation in psychology is defined as judgements, feelings, and activities that are planned and implemented in order to achieve a personal goal (Zimmerman, 2002). Social Learning theory considers self-regulation as a mixture of personal, behavioural and environmental processes (Bandura \& Walters, 1977). There is research evidence that indicates the effect of self-regulation on learning on student's performance and achievement (Azevedo \& Cromley, 2004) and the amount of depth of student thinking (Jenson, 2011). Additionally, students' conscious focus on the learning process (Ottenhoff, 2011), and the acquisition of reflective and responsible competence (Sluijsmans et al., 2002) has been declared to be dependable of selfregulation.

A self-regulated student can monitor his or her learning and has the ability to identify and implement strategies to succeed (Miller, 2015). This ability is a critical skill for online learning environments as it is characterised with autonomy (Barnard et al., 2009). In the FC model, learners are actively engaged participants and leaders in their learning processes. Therefore, self-regulation has an important role to ensure students engage with online resources before the classroom. To measure self-regulation in online learning settings, a set of subscales are used to guide the developing of questionnaire items (Self-Regulation Questionnaires). These subscales have been reviewed extensively (Nota et al., 2004; Pintrich \& Zusho, 2007; Schunk 
\& Zimmerman, 1997; Zimmerman \& Schunk, 2011). Table 1 present these subscales and a brief description.

Table 1: Self-regulation subscales for online learning

\begin{tabular}{|l|l|}
\hline Subscale & Description \\
\hline $\begin{array}{l}\text { Environment } \\
\text { structuring }\end{array}$ & $\begin{array}{l}\text { Students must be in a position to structure } \\
\text { their physical learning environment, whether } \\
\text { at home or elsewhere to avoid distractions } \\
\text { (Zimmerman, 1995). }\end{array}$ \\
\hline Goal setting & $\begin{array}{l}\text { A critical component of self-regulatory } \\
\text { learning, is described as learners' goals or } \\
\text { orientation towards their studies (Pintrich, } \\
\text { 1991). }\end{array}$ \\
\hline Time management & $\begin{array}{l}\text { Includes "scheduling, planning, and } \\
\text { managing one's study time." (Chen, 2002). }\end{array}$ \\
\hline Task strategies & $\begin{array}{l}\text { This is referred on how students approach } \\
\text { the learning task such as note taking, } \\
\text { prepare questions before the classroom, } \\
\text { joining the chat room and discussion forums, } \\
\text { and so on (Zimmerman, 2002). }\end{array}$ \\
\hline Help seeking & $\begin{array}{l}\text { Ability to pursue academic help in an } \\
\text { "adaptive manner" and to promote learning } \\
\text { (Lynch \& Dembo, 2004). }\end{array}$ \\
\hline Self-evaluation & $\begin{array}{l}\text { Capacity to evaluate personal effectiveness } \\
\text { concerning specific learning tasks. Students } \\
\text { that can evaluate their learning they become } \\
\text { more self-regulated learners (Winne \& } \\
\text { Hadwin, 1998). }\end{array}$ \\
\hline Self-consequences & $\begin{array}{l}\text { Student thinking of reward or punishment for } \\
\text { success or failure in a learning task (Nota et } \\
\text { al., 2004). }\end{array}$ \\
\hline & \\
\hline
\end{tabular}

\subsection{Motivational factors}

Motivational factors are considered in educational psychology the sine qua non of selfregulation processes. The most important motivational factors can be identified as selfefficacy, goal orientations, task value, attributions for failure and anxiety. Table 2 presents a brief description of each of these factors.

Table 2: Motivational factors for self-regulation

\begin{tabular}{|l|l|}
\hline Factor & Description \\
\hline Self-efficacy & $\begin{array}{l}\text { Can be defined as a belief in one's ability to } \\
\text { succeed or accomplish a task. Self-efficacy } \\
\text { is envisaged a fundamental factor for self- } \\
\text { regulation (Bandura, 1986). A positive } \\
\text { relationship has been established between } \\
\text { self-efficacy and self-regulation (Pintrich \& } \\
\text { Zusho, 2007). }\end{array}$ \\
\hline
\end{tabular}




\begin{tabular}{|l|l|}
\hline Goal orientations & $\begin{array}{l}\text { A disposition toward developing or } \\
\text { demonstrating ability in achievement } \\
\text { situations (Pintrich, 2000). There are two } \\
\text { types of goals: learning-oriented (or } \\
\text { mastered-oriented) and performance goals } \\
\text { (social or ego goals)(Meece et al., 1988). }\end{array}$ \\
\hline Task value & $\begin{array}{l}\text { Students' perceptions of the interest, } \\
\text { usefulness, importance and cost of a task } \\
\text { (Meece et al., 1988). Students who attach a } \\
\text { high value to the task will use deeper } \\
\text { cognitive and metacognitive strategies for } \\
\text { learning (Pintrich, 2004). }\end{array}$ \\
\hline Attributions for failure & $\begin{array}{l}\text { Attribution theory studies how individuals } \\
\text { understand events and how this relates to } \\
\text { their thinking and behaviour. For example, } \\
\text { students who rate uncontrollable factors } \\
\text { (luck, ability and task difficulty) as their } \\
\text { reason for failure or success does not have } \\
\text { learning tendencies (Licht \& Dweck, 1984). }\end{array}$ \\
\hline Anxiety & $\begin{array}{l}\text { Can affect negatively self-regulated learning } \\
\text { undermining cognitive and metacognitive } \\
\text { learning processes (Zimmerman, 1989). }\end{array}$ \\
\hline
\end{tabular}

In summary, self-regulation subscales and motivational factors act together and make a powerful effect on learning and achievement. These concepts will be utilised to propose the model in the next section and to develop an evaluative strategy for FC.

\section{THE WAVE MODEL TO EVALUATE FLIPPED CLASSROOMS}

The wave model uses an analogy on how waves are created in the ocean by the wind. When the wind responds to the surface water, friction occurs between air molecules and water molecules. The energy generated from the wind is taken to the water and forms the waves. The stronger the wind; the larger the waves.

In the case of flipped classroom, the first wave is initiated when students engage with content before the classroom. Knowledge acquired independently help students to examine and consider their ideas with their peers and tutors during the classroom. In the classroom, a second wave is generated where the students reinforce what they have learnt with the preparation and via active learning. When students return home, they will be given the opportunity to engage with what they learnt and with additional content, forming the third wave. These waves will be breaking continuously and advancing student's understanding of the subject during the semester.

The role of self-regulation theory and motivational factors can be incorporated into each of the three steps of the FC, before, during and after the classroom. For instance, before the classroom, students need to have a goal setting, environment structuring and time management to effectively engage with the preparation content. During the classroom, students will need to seek help from their peers and tutors, and to have task strategies. In contrast, after the classroom, students will be required to engage in self-evaluation and selfconsequences. Motivational factors previously discussed need to be present (Graph 1).

Coming back to the analogy, the wind will be the motivational factors for self-regulation provided in Table 2 (Bandura, 1986; Licht \& Dweck, 1984; Meece et al., 1988; Pintrich, 2004; Pintrich \& Zusho, 2007; Zimmerman, 1989). 


\section{Graph 1: The Wave Model of Self-Regulated Learning in FC}
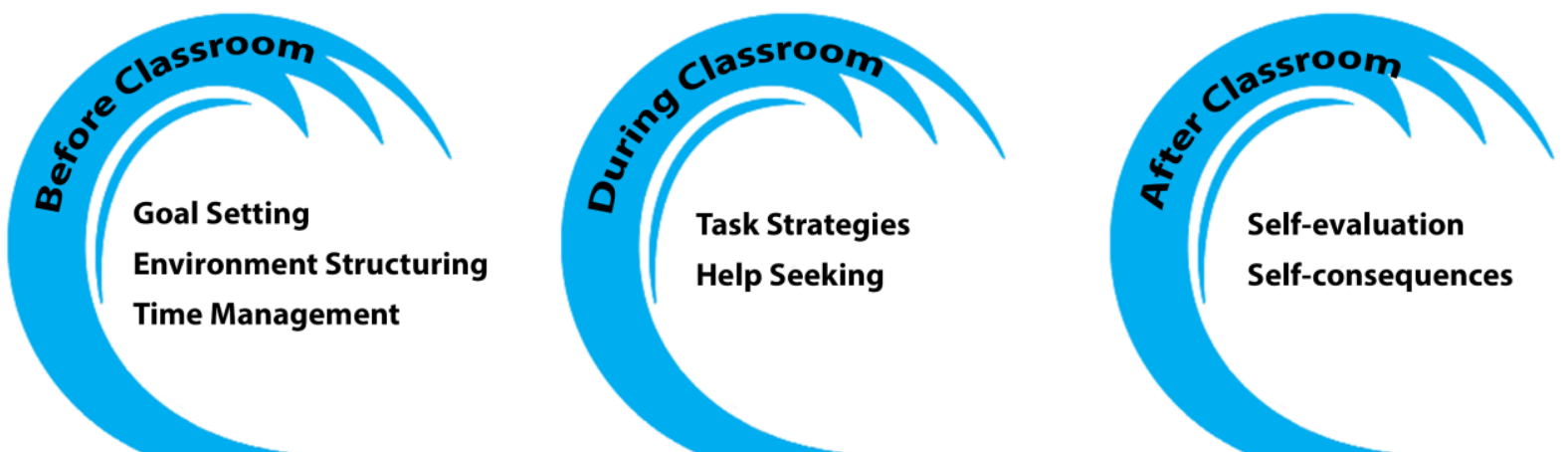

Motivational Factors: Self-efficacy, goal orientations, task value, attributions for failure, anxiety

Graph 1 presents the wave model of self-regulated learning predicted to happen when FC are used as an instructional approach. The mapping of each wave with self-regulation subscales helped to develop an evaluative strategy. A Self-Regulated Learning Questionnaire for FC (SLQ-FC) was developed adapting Barnard's et al., 2009 Online Self-Regulated Questionnaire (OSLQ), Table 3.

Table 3: Self-Regulated Learning Questionnaire for FC adapted from Barnard et al., (2009)

\begin{tabular}{|l|l|}
\hline Subscale & Item \\
\hline Goal setting & $\begin{array}{l}\text { I set standards for my learning. } \\
\text { I set short-term (daily or weekly) goals as well as long- } \\
\text { term goals (monthly or for the semester). } \\
\text { I keep a high standard for my learning in my preparation } \\
\text { for the classroom } \\
\text { I set goals to help me manage studying time for my } \\
\text { preparation for the classroom } \\
\text { I don't compromise the quality of my preparation before } \\
\text { the classroom work because it is online. }\end{array}$ \\
\hline Environment structuring & $\begin{array}{l}\text { I choose the location where I study to avoid too much } \\
\text { distraction. } \\
\text { I find a comfortable place to study. } \\
\text { I know where I can study most efficiently for my } \\
\text { preparation for the classroom } \\
\text { I choose a time with few distractions for studying for } \\
\text { preparation for the classroom }\end{array}$ \\
\hline Time management & $\begin{array}{l}\text { I allocate extra studying time for online content because I } \\
\text { know it is time-demanding. } \\
\text { I try to schedule the same time every day or every week } \\
\text { to prepare before the classroom, and I observe the } \\
\text { schedule. }\end{array}$ \\
\hline
\end{tabular}




\begin{tabular}{|c|c|}
\hline & $\begin{array}{l}\text { Although we don't have to attend daily classes, I still try to } \\
\text { distribute my studying time evenly across days. }\end{array}$ \\
\hline Task strategies & $\begin{array}{l}\text { I try to take more thorough notes for my preparation before } \\
\text { the classroom because notes are even more important for } \\
\text { learning online than in a regular classroom. } \\
\text { I read aloud instructional materials posted online to fight } \\
\text { against distractions } \\
\text { I prepare my questions before the classroom } \\
\text { I work extra problems in my preparation before the } \\
\text { classroom in addition to the assigned ones to master the } \\
\text { course content. }\end{array}$ \\
\hline Help seeking & $\begin{array}{l}\text { I find someone who is knowledgeable in course content so } \\
\text { that I can consult with him or her when I need help. } \\
\text { I share my problems with my classmates online, so we } \\
\text { know what we are struggling with and how to solve our } \\
\text { problems. } \\
\text { If needed, I try to meet my classmates face-to-face. } \\
\text { I am persistent in getting help from the instructor and } \\
\text { peers during the classroom }\end{array}$ \\
\hline Self-evaluation & $\begin{array}{l}\text { I summarise my learning to examine my understanding of } \\
\text { what I have learned. } \\
\text { I ask myself a lot of questions about the preparation } \\
\text { material before the classroom. } \\
\text { I communicate with my classmates to find out how I am } \\
\text { doing in my preparation for the classroom. } \\
\text { I communicate with my classmates to find out what I am } \\
\text { learning that is different from what they are learning. }\end{array}$ \\
\hline Self-consequences & $\begin{array}{l}\text { I reward myself when I prepare for the classroom } \\
\text { I punish myself if I do not prepare for the classroom }\end{array}$ \\
\hline
\end{tabular}

\section{DISCUSSION}

The wave model was designed to address the need for an evidence-based instrument to measure self-regulation during FC. A Self-Regulated Learning Questionnaire for FC (SLQ-FC) is proposed based on an adjustment of Barnard et al., (2009) validated Online Self-Regulated Questionnaire (OSLQ). Confirmatory factor analyses (Beavers et al., 2013; Williams et al., 2010) have to be undertaken to assess the design, administration and interpretation of the proposed questionnaire and determine the construct validity of the instrument. Data points can be gathered from the students at the beginning, in the middle and towards the end of the semester. Students must be identifiable to track their progress. Additionally, interviews can be held with students who self-regulated their learning vs. students who did not. This data can provide an in-depth understanding how students self-regulate when FC is used as a mode of instruction. Surfing the waves of self-regulated learning in FC can inform future design and improvement of this mode of instruction.

\section{REFERENCES}

Abeysekera, L., \& Dawson, P. (2015). Motivation and cognitive load in the flipped classroom: definition, rationale and a call for research. Higher Education Research \& Development, 34(1), 1-14. doi:10.1080/07294360.2014.934336

Azevedo, R., \& Cromley, J. G. (2004). Does training on self-regulated learning facilitate students' learning with hypermedia? Journal of educational psychology, 96(3), 523.

Bandura, A. (1986). The explanatory and predictive scope of self-efficacy theory. Journal of social and clinical psychology, 4(3), 359-373. 
Bandura, A., \& Walters, R. H. (1977). Social learning theory.

Barnard, L., Lan, W. Y., To, Y. M., Paton, V. O., \& Lai, S.-L. (2009). Measuring self-regulation in online and blended learning environments. The Internet and Higher Education, 12(1), 1-6.

Beavers, A. S., Lounsbury, J. W., Richards, J. K., Huck, S. W., Skolits, G. J., \& Esquivel, S. L. (2013). Practical considerations for using exploratory factor analysis in educational research. Practical assessment, research \& evaluation, 18(6), 1-13.

Bergmann, J., \& Sams, A. (2012). Flip your classroom: Reach every student in every class every day: International Society for Technology in Education.

Bishop, J. L., \& Verleger, M. A. (2013). The flipped classroom: A survey of the research. Paper presented at the ASEE National Conference Proceedings, Atlanta, GA.

Chen, C. S. (2002). Self-regulated learning strategies and achievement in an introduction to information systems course. Information Technology, learning, and performance Journal, 20(1), 11.

Chen, H. Y. L., Chen, N. S., \& leee. (2014). Design and Evaluation of a Flipped Course Adopting the Holistic Flipped Classroom Approach. 2014 14th leee International Conference on Advanced Learning Technologies (Icalt), 627-631. doi:10.1109/icalt.2014.183

Clark, R. C., Nguyen, F., \& Sweller, J. (2011). Efficiency in learning: Evidence-based guidelines to manage cognitive load: John Wiley \& Sons.

Du, S. C., Fu, Z. T., \& Wang, Y. (2014). The Flipped Classroom-Advantages and Challenges. Proceedings of the 2014 International Conference on Economic Management and Trade Cooperation, 107, 17-20.

Huan, C. (2016). A Study on Digital Media Technology Courses Teaching Based on Flipped Classroom. American Journal of Educational Research, 4(3), 264-267.

Jenson, J. D. (2011). Promoting self-regulation and critical reflection through writing students' use of electronic portfolio. International Journal of ePortfolio, 1(1), 49-60.

Kachka, P. (2012). Understanding the flipped classroom: Part 2. Faculty Focus, 23.

Lane, S. (2015). Servant Leadership: Empowering Learners through ${ }^{\circ} / E F l i p p e{ }^{\circ} \varnothing$ Classrooms. American Journal of Educational Research, 3(11), 1211-1216.

Licht, B. G., \& Dweck, C. S. (1984). Determinants of academic achievement: The interaction of children's achievement orientations with skill area. Developmental psychology, 20(4), 628.

Lynch, R., \& Dembo, M. (2004). The relationship between self-regulation and online learning in a blended learning context. The International Review of Research in Open and Distributed Learning, 5(2).

McLaughlin, J. E., Griffin, L. M., Esserman, D. A., Davidson, C. A., Glatt, D. M., Roth, M. T., . . Mumper, R. J. (2013). Pharmacy student engagement, performance, and perception in a flipped satellite classroom. American Journal of Pharmaceutical Education, 77(9), 196.

Meece, J. L., Blumenfeld, P. C., \& Hoyle, R. H. (1988). Students' goal orientations and cognitive engagement in classroom activities. Journal of educational psychology, 80(4), 514.

Miller, D. A. (2015). Learning How Students Learn: An Exploration of Self-Regulation Strategies in a Two-Year College General Chemistry Class. Journal of College Science Teaching, 44(3), 1116.

Moraros, J., Islam, A., Yu, S., Banow, R., \& Schindelka, B. (2015). Flipping for success: evaluating the effectiveness of a novel teaching approach in a graduate level setting. Bmc Medical Education, 15. doi:10.1186/s12909-015-0317-2

Nota, L., Soresi, S., \& Zimmerman, B. J. (2004). Self-regulation and academic achievement and resilience: A longitudinal study. International Journal of Educational Research, 41(3), 198-215.

O'Flaherty, J., \& Phillips, C. (2015). The use of flipped classrooms in higher education: A scoping review. The Internet and Higher Education, 25, 85-95. 
Ottenhoff, J. (2011). Learning How to Learn: Metacognition in Liberal Education. Liberal Education, 97, 28-33.

Phillips, R., McNaught, C., \& Kennedy, G. (2012). Evaluating e-learning: Guiding research and practice: Routledge.

Pintrich, P. R. (1991). A manual for the use of the Motivated Strategies for Learning Questionnaire (MSLQ).

Pintrich, P. R. (2000). The role of goal orientation in self-regulated learning: Academic Press.

Pintrich, P. R. (2004). A conceptual framework for assessing motivation and self-regulated learning in college students. Educational psychology review, 16(4), 385-407.

Pintrich, P. R., \& Zusho, A. (2007). Student Motivation and Self-Regulated Learning in the College Classroom. In R. P. Perry \& J. C. Smart (Eds.), The Scholarship of Teaching and Learning in Higher Education: An Evidence-Based Perspective (pp. 731-810). Dordrecht: Springer Netherlands.

Reyna, J. (2015). Active Learning and the Flipped Classroom (FC). Training and Development Magazine, Vol 42(3), 31-32.

Schunk, D. H., \& Zimmerman, B. J. (1997). Social origins of self-regulatory competence. Educational psychologist, 32(4), 195-208.

Shell, A. E. (2002). The Thayer Method of Instruction at the United States Military Academy: A modest History and a Modern Personal Account. Primus, 12(1), 27-38. doi:10.1080/10511970208984015

Sluijsmans, D. M., Brand-Gruwel, S., van Merriënboer, J. J., \& Bastiaens, T. J. (2002). The training of peer assessment skills to promote the development of reflection skills in teacher education. Studies in Educational Evaluation, 29(1), 23-42.

Straw, S., Quinlan, O., Harland, J.,Walker, M. (2015). Flipped learning research report. NFER.

Williams, B., Onsman, A., \& Brown, T. (2010). Exploratory factor analysis: A five-step guide for novices. Australasian Journal of Paramedicine, 8(3).

Winne, P. H., \& Hadwin, A. F. (1998). Studying as self-regulated learning. Metacognition in educational theory and practice, 93, 27-30.

Zimmerman, B. J. (1989). A social cognitive view of self-regulated academic learning. Journal of educational psychology, 81(3), 329.

Zimmerman, B. J. (1995). Self-regulation involves more than metacognition: A social cognitive perspective. Educational psychologist, 30(4), 217-221.

Zimmerman, B. J. (2002). Achieving academic excellence: A self-regulatory perspective. The pursuit of excellence through education, 85-110.

Zimmerman, B. J., \& Schunk, D. (2011). Motivational sources and outcomes of self-regulated learning and performance. Handbook of self-regulation of learning and performance, 49-64. 